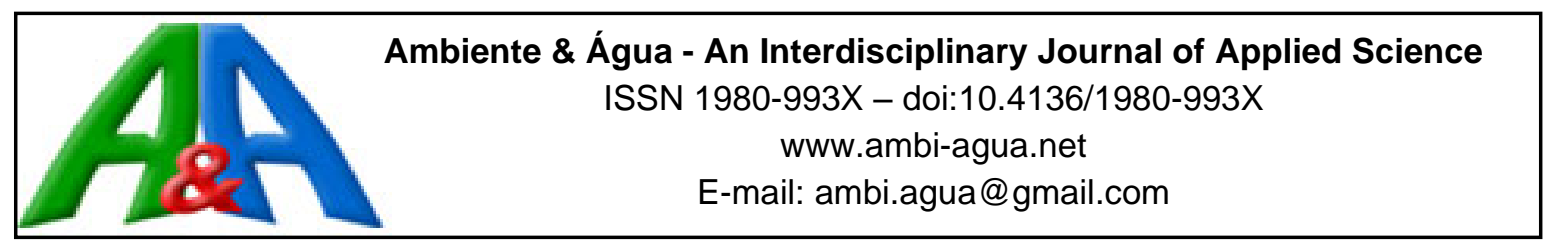

\title{
Extreme rainfall and IDF equations for Alagoas State, Brazil
}

\author{
ARTICLES doi:10.4136/ambi-agua.2544
}

Received: 17 Mar. 2020; Accepted: 11 Sep. 2020

\begin{abstract}
Álvaro José Back ${ }^{1 *}$; Sabrina Baesso Cadorin² ${ }^{\circledR}$; Sérgio Luciano Galatto ${ }^{3}$
${ }^{1}$ Estação Experimental de Urussanga. Empresa de Pesquisa Agropecuária e Extensão Rural de Santa Catarina (EPAGRI), Rodovia SC 108, km 353, nº 1563, CEP: 88840-000, Urussanga, SC, Brazil.

${ }^{2}$ Programa de Pós-Graduação em Ciências Ambientais. Universidade do Extremo Sul Catarinense (UNESC), Avenida Universitária, $\mathrm{n}^{\circ}$ 1105, CEP: 88806-000, Criciúma, SC, Brazil. E-mail: bcadorin.sabrina@gmail.com ${ }^{3}$ Instituto de Pesquisas Ambientais e Tecnológicas. Centro de Pesquisa e Estudos Ambientais. Universidade do Extremo Sul Catarinense (UNESC), Rodovia Governador Jorge Lacerda, km 4,5, nº 3800, CEP: 88807-400,

Criciúma, SC, Brazil. E-mail: sga@unesc.net

*Corresponding author. E-mail: ajb@epagri.sc.gov.br
\end{abstract}

\begin{abstract}
Intensity-duration-frequency (IDF) equations have important applications in several engineering areas such as urban drainage designs, hydrological modeling, and soil conservation projects. This study analyzes the annual maximum series and fits IDF equations for 44 rainfall stations in Alagoas State, Brazil. We adjusted parameters of the Gumbel distribution (GD) and the Generalized Extreme Value (GEV) distribution. The fitting of the observed data to the probability distributions, as well as the selection of the best distribution, were based on the Kolmogorov-Smirnov and Anderson-Darling tests at a 5\% significance level. The GEV distribution with parameters obtained by the L-moments method was considered the best in $73 \%$ of rainfall stations. The estimated IDF equations showed a good fit, with determination coefficients above 0.991 . The maximum rainfall intensities have spatial variation following the climatic zones of the state. The fitted equations allow estimating rainfall intensities from 5 minutes to 24 hours with a return period of 2 to 100 years, and standard error of less than $6.83 \mathrm{~mm} \mathrm{~h}^{-1}$.
\end{abstract}

Keywords: drainage, probabilities, water resources.

\section{Chuvas intensas e equações IDF para o estado de Alagoas, Brasil}

\section{RESUMO}

As equações IDF tem importante aplicação em diversas áreas da engenharia como nos projetos de drenagem urbana, na modelagem hidrológica e em projetos de conservação do solo. Este trabalho teve como objetivo analisar as séries de máximas anuais e ajustar as equações IDF para 44 estações pluviométricas do estado de Alagoas, Brasil. Foram ajustados os parâmetros da distribuição de Gumbel e da distribuição Generalizada de Valores Extremos. A avaliação da aderência dos dados observados às distribuições de probabilidade bem como a seleção da melhor distribuição foi baseada nos testes de Kolmogorov-Smirnov e AndersonDarling, ao nível de significância de 5\%. A distribuição GEV com parâmetros obtidos pelo método dos L-Momentos foi considerada a melhor em $73 \%$ das estações pluviométricas. As equações IDF estimadas apresentaram um bom ajuste, com coeficientes de determinação acima de 0,991 . As intensidades de chuvas máximas têm variação espacial acompanhando as zonas 
Álvaro José Back et al.

climáticas do estado. As equações ajustadas permitem estimativa da intensidade da chuva com duração de 5 minutos a 24 horas e período de retorno de 2 a 100 anos, com erro padrão de estimativa inferior $6,83 \mathrm{~mm} \mathrm{~h}^{-1}$.

Palavras-chave: drenagem, probabilidades, recursos hídricos.

\section{INTRODUCTION}

Excessive rainfall can cause agricultural losses, soil erosion, and flooding. In addition to causing material damage, these events represent a major risk to life, especially in urban areas. Thus, knowledge about extreme rainfall in a given location has great application in urban and agricultural planning, besides being used in environmental risk analysis, water infrastructure projects, irrigation, and dimensioning of engineering drawings (Deng et al., 2017; Coelho Filho et al., 2017).

To characterize extreme rainfall, one must know the intensity, duration of the event, and the frequency of occurrence, which can be represented by intensity-duration-frequency (IDF) curves and equations (Silveira, 2016). These equations have great application in the hydrological dimensioning of urban drainage structures, in hydrological models for flow estimation, and in agricultural drainage and soil conservation (Marra et al., 2017; Ouali and Cannon, 2018).

Intensity-duration-frequency equations are determined using traditional methods based on data from rainfall stations (Martins et al., 2017; Tfwala et al., 2017). In the absence or scarcity of long data series, information from rainfall stations is gathered, and the maximum 1-day rainfall is clipped to shorter rainfall events, thus allowing the fitting of equations (Penner and Lima, 2016; Rangel and Hartwig, 2017; Dias and Penner, 2019). Some studies assess the possibility of using satellite or radar observations to obtain IDF equations (Marra et al., 2017).

Mirzaei et al. (2014) claim that is important to assess the uncertainties related to extreme rainfall estimates and to propagate those uncertainties into design decisions and risk assessment, and point out that uncertainty in depth-duration-frequency curves is usually disregarded in the view of difficulties associated in assigning a value to it. Mirzaei et al. (2015) investigated uncertainties incorporated in the distribution function of the series of annual maximum daily rainfall.

There are different statistical distributions of extreme events that can be used to fit a set of hydrological data. Among them is Gumbel, which is the most used for fitting data in studies of extreme rainfall (Gonçalves et al., 2019; Petrucci and Oliveira, 2019). Another distribution that has been shown to be quite adequate to represent extreme natural events such as heavy rainfall is the Generalized Extreme Value (GEV) distribution (Quadros et al., 2011; Tfwala et al., 2017). Olofintoye et al. (2009) point out that many statistical distributions can be applied to describe extreme annual rainfall events in a given location. However, choosing the appropriate model is one of the biggest problems in engineering practice, as there is no general agreement on which distribution or distributions to use in the analysis of extreme rainfall frequency. The selection of the appropriate model depends mainly on the characteristics of the available rainfall data for a particular station. That is why it is necessary to evaluate several distributions to find the model that allows obtaining the best extreme rainfall estimates.

In Alagoas State there is a lack of information on IDF equations (Dias and Penner, 2017). Thus, the present study analyzes the maximum annual rainfall and determines IDF equations in 44 rainfall stations distributed throughout Alagoas State, Brazil.

\section{MATERIALS AND METHODS}

Alagoas State is bathed by the Atlantic Ocean and borders the states of Pernambuco,

Rev. Ambient. Água vol. 15 n. 6, e2544 - Taubaté 2020 
Sergipe, and Bahia. The state is located between latitudes $8^{\circ} 54^{\prime} 57^{\prime \prime} \mathrm{S}$ and $9^{\circ} 19^{\prime} 50^{\prime \prime} \mathrm{S}$ and longitudes $35^{\circ} 09^{\prime} 08^{\prime \prime} \mathrm{W}$ and $38^{\circ} 13^{\prime} 38^{\prime \prime} \mathrm{W}$. The relief is divided into three major types, starting from east to west through the coastal plain, followed by the tablelands region, and the plateau that corresponds to most of the Alagoas territory. According to Barros et al. (2012), the annual rainfall averages in Alagoas State vary from 2,000 mm, on the coast, to $400 \mathrm{~mm}$ in the hinterlands (Sertão). These values gradually decrease from east to west.

Climatic variation throughout the state is quite significant. According to the Köppen climate classification, Alagoas State is divided into four zones. There is the occurrence of humid tropical climate (Ams) and semi humid tropical climate (As) in the most coastal region of the state, which corresponds to the forest zone, the most humid part of the Agreste region, and the coast. Such climates are characterized by abundant rains throughout the year and a well-defined dry season. To the west of Alagoas, in the Agreste and Sertão, climatic classification comprises the driest types, with a hot semi arid climate (BSsh), in which evaporation exceeds rainfall. There is also the presence of As climate in a small area northwest of the state (Barros et al., 2012).

The study included rainfall data from 44 rainfall stations located in Alagoas State, belonging to the Hydrological Network of the National Water Agency (ANA). We selected stations that presented at least 20 years of data. Table 1 contains the stations used, their respective coordinates, historical series, and climate data. Figure 1 shows the spatial distribution of these stations.

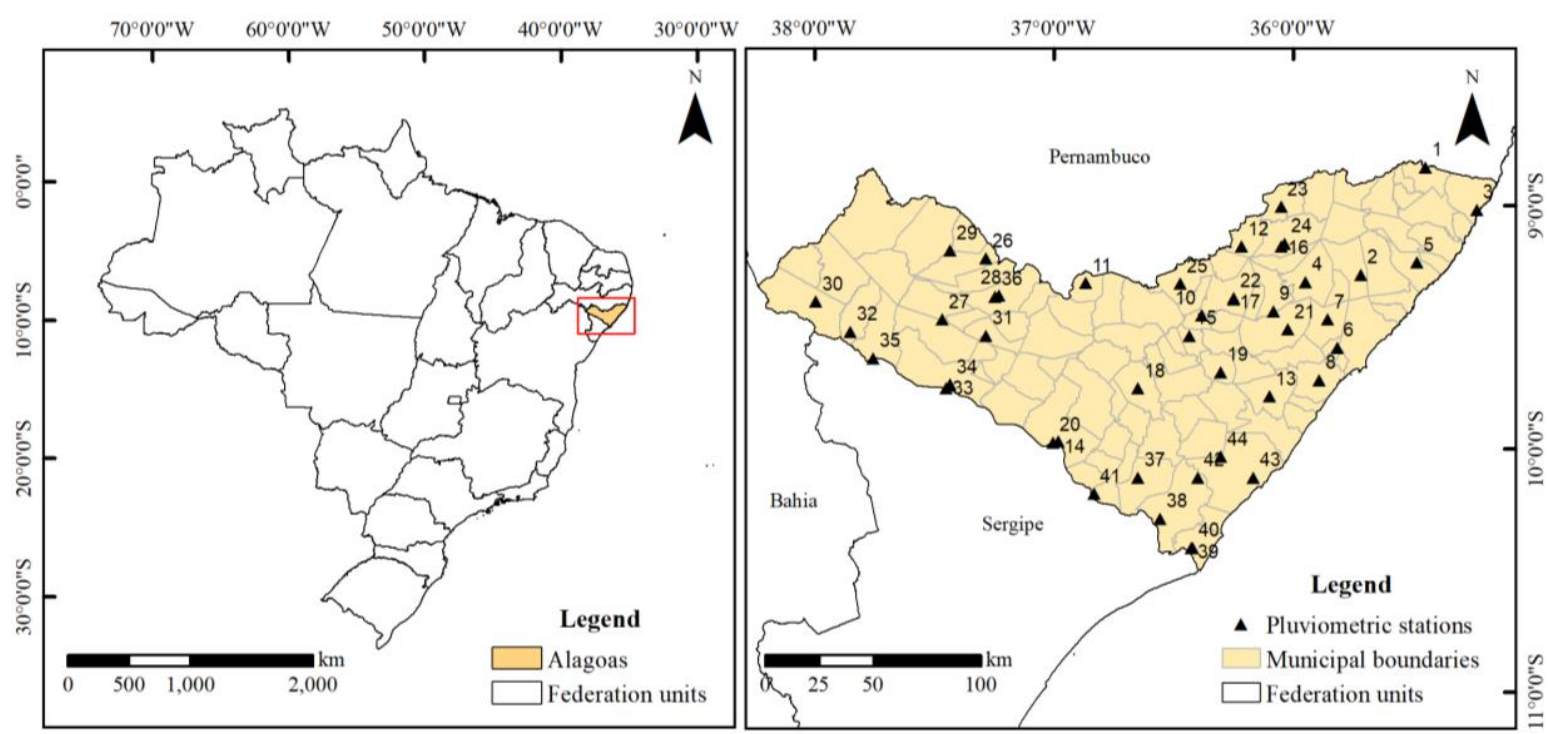

Figure 1. Location map of the rainfall stations used.

To analyze the historical series of extreme rainfall data, we used the Gumbel distribution (GD) (Type I distribution of extremes) and the Generalized Extreme Value (GEV) distribution, whose probability density functions (PDFs) are given, respectively, by Equations 1 and 2:

$$
\begin{aligned}
& f(x)=\frac{1}{\alpha} \operatorname{Exp}\left[-\frac{X-\beta}{\alpha}-\left(-\frac{X-\beta}{\alpha}\right)\right] \\
& f(x)=\frac{1}{\alpha}\left[1-k\left(\frac{X-\beta}{\alpha}\right)\right]^{\left(\frac{1}{k-1}\right)} \operatorname{Exp}\left\{-\left[1-k\left(\frac{X-\beta}{\alpha}\right)\right]^{\left(\frac{1}{k}\right)}\right\}
\end{aligned}
$$

Where $\mathrm{x}$ is the maximum annual daily rainfall; $\alpha, \beta$, and $\mathrm{k}$ are parameters of the probability distribution (De Alcântara et al., 2019). 
Table 1. Location and data of the selected stations.

\begin{tabular}{|c|c|c|c|c|c|c|c|}
\hline No. & Code & City & $\begin{array}{l}\text { Latitude } \\
\quad\left({ }^{\circ} \mathbf{S}\right)\end{array}$ & $\begin{array}{c}\text { Longitude } \\
\left({ }^{\circ} \mathbf{W}\right)\end{array}$ & Period & No. years & Climate \\
\hline 1 & 835139 & Jacuípe & 8.8419 & 35.4475 & $1990-2018$ & 29 & Am \\
\hline 2 & 935001 & Flexeiras & 9.2833 & 35.7167 & $1963-2000$ & 31 & As \\
\hline 3 & 935010 & Maragogi & 9.0167 & 35.2333 & $1963-1991$ & 26 & Am \\
\hline 4 & 935012 & Murici & 9.3136 & 35.9497 & $1963-2018$ & 53 & As \\
\hline 5 & 935013 & Passo de Camaragibe & 9.2333 & 35.4833 & $1957-1991$ & 34 & Am \\
\hline 6 & 935023 & Satuba & 9.5833 & 35.8167 & 1963-1991 & 28 & Am \\
\hline 7 & 935056 & Rio Largo & 9.4675 & 35.8564 & $1990-2018$ & 27 & As \\
\hline 8 & 935057 & Marechal Deodoro & 9.7164 & 35.8917 & $1991-2018$ & 28 & Am \\
\hline 9 & 936014 & Capela & 9.4333 & 36.0833 & $1963-1988$ & 26 & As \\
\hline 10 & 936031 & Mar Vermelho & 9.4500 & 36.3833 & 1963-1994 & 30 & As \\
\hline 11 & 936032 & Palmeira dos Índios & 9.3167 & 36.8667 & 1963-1989 & 26 & As \\
\hline 12 & 936045 & Santana do Mundaú & 9.1667 & 36.2167 & $1963-2000$ & 34 & As \\
\hline 13 & 936048 & São Miguel Dos Campos & 9.7833 & 36.1000 & $1921-1984$ & 61 & As \\
\hline 14 & 936051 & Traipu & 9.9667 & 36.9833 & 1946-1998 & 49 & As \\
\hline 15 & 936052 & Tanque D'arca & 9.5333 & 36.4333 & $1963-2000$ & 32 & As \\
\hline 16 & 936053 & União dos Palmares & 9.1667 & 36.0500 & 1913-1991 & 71 & As \\
\hline 17 & 936057 & Viçosa & 9.3833 & 36.2500 & $1913-1989$ & 74 & As \\
\hline 18 & 936066 & Arapiraca & 9.7500 & 36.6500 & 1964-1991 & 24 & As \\
\hline 19 & 936070 & Anadia & 9.6836 & 36.3036 & 1913-1987 & 72 & As \\
\hline 20 & 936076 & Traipu & 9.9728 & 37.0033 & $1973-2018$ & 41 & As \\
\hline 21 & 936110 & Atalaia & 9.5072 & 36.0233 & $1990-2018$ & 28 & As \\
\hline 22 & 936111 & Viçosa & 9.3792 & 36.2492 & $1990-2018$ & 28 & As \\
\hline 23 & 936112 & São José da Laje & 9.0042 & 36.0511 & $1991-2018$ & 28 & As \\
\hline 24 & 936113 & União dos Palmares & 9.1544 & 36.0358 & $1991-2018$ & 28 & As \\
\hline 25 & 936115 & Quebrangulo & 9.3192 & 36.4731 & $1991-2010$ & 20 & As \\
\hline 26 & 937004 & Poço das Trincheiras & 9.2167 & 37.2833 & 1921-1989 & 64 & As \\
\hline 27 & 937005 & Santana do Ipanema & 9.4667 & 37.4667 & 1964-1994 & 28 & As \\
\hline 28 & 937006 & Santana do Ipanema & 9.3672 & 37.2292 & 1913-1991 & 69 & As \\
\hline 29 & 937012 & Canapi & 9.1833 & 37.4333 & $1938-1991$ & 50 & As \\
\hline 30 & 937013 & Delmiro Gouvéia & 9.3928 & 37.9942 & $1937-2018$ & 77 & BSh \\
\hline 31 & 937016 & Olho D’água das Flores & 9.5333 & 37.2833 & 1963-1989 & 25 & As \\
\hline 32 & 937017 & Olho D’água do Casado & 9.5167 & 37.8500 & 1963-1991 & 29 & As \\
\hline 33 & 937018 & Pão de Açúcar & 9.7486 & 37.4497 & $1982-2018$ & 36 & BSh \\
\hline 34 & 937019 & Pão de Açúcar & 9.7333 & 37.4333 & 1913-1985 & 63 & BSh \\
\hline 35 & 937023 & Piranhas & 9.6261 & 37.7561 & $1935-2018$ & 73 & BSh \\
\hline 36 & 937032 & Santana do Ipanema & 9.3728 & 37.2453 & 1979-2018 & 36 & As \\
\hline 37 & 1036003 & Igreja Nova & 10.1167 & 36.6500 & 1964-1999 & 32 & As \\
\hline 38 & 1036005 & Penedo & 10.2850 & 36.5564 & $1935-2018$ & 82 & As \\
\hline 39 & 1036007 & Piaçabuçú & 10.4064 & 36.4261 & $1929-2018$ & 80 & As \\
\hline 40 & 1036008 & Piaçabuçú & 10.4053 & 36.4219 & $1929-2000$ & 60 & As \\
\hline 41 & 1036009 & Porto Real do Colégio & 10.1833 & 36.8333 & 1913-1991 & 74 & As \\
\hline 42 & 1036011 & Coruripe & 10.1167 & 36.4000 & $1963-1991$ & 27 & As \\
\hline 43 & 1036013 & Coruripe & 10.1167 & 36.1667 & $1937-1984$ & 45 & As \\
\hline 44 & 1036062 & Coruripe & 10.0314 & 36.3039 & $1990-2018$ & 27 & As \\
\hline
\end{tabular}

The parameters of the Gumbel distribution were estimated using the Moments (MM), Maximum Likelihood (MLM), and L-moments (MML) methods (Naghettini and Pinto, 2007), in addition to the method proposed by Chow (CH) (Back and Bonetti, 2014). The parameters of the GEV distribution were adjusted by the Moments (MM) and L-moments (MML) methods (Naghettini and Pinto, 2007).

Following De Alcântara et al. (2019), two tests were used to analyze the fitting to the distribution: Kolmogorov-Smirnov (KS) and Anderson-Darling (AD), considering the ranking of distributions and the respective methods of estimating parameters. The distribution with the 
lowest sum of the ranks of the two tests was selected.

Using the selected distribution for each data series, the values of maximum daily rainfall with return periods of $2,5,10,15,25,50$, and 100 years were determined. The breakdown of daily rainfall into shorter duration rainfall followed the methodology proposed by CETESB (1986), estimating maximum rainfall intensities for 5, 10, 15, 20, 25, 30, 60, 360, 720, and 1440 minutes.

With the values obtained from maximum rainfall intensities for different durations and return times, we determined the parameters of the Equation 3 that expresses IDF:

$$
I=\frac{K T^{m}}{(t+b)^{n}}
$$

Where: $\mathrm{I}$ is the average maximum rainfall intensity $\left(\mathrm{mm} \mathrm{h}^{-1}\right) ; \mathrm{K}, \mathrm{m}, \mathrm{b}, \mathrm{n}$ are the coefficients to be fitted; $\mathrm{T}$ is the return period (years); $\mathrm{t}$ is the rainfall duration (minutes).

To fit the Equation 4, we minimized the standard error (RMSE), expressed by:

RMSE $=\sqrt{\frac{\sum_{\mathrm{j}=1}^{\mathrm{n}}\left(\mathrm{G}_{\mathrm{T}}^{\mathrm{t}}-\mathrm{I}_{\mathrm{T}}^{\mathrm{t}}\right)^{2}}{\mathrm{n}}}$

With the IDF equations obtained for each station, we determined rainfall intensity for different durations $(15,30$, and 60 minutes, and maximum daily rainfall with a 10 -year return period). To represent the spatial distribution of extreme rainfall, data were interpolated in ArcGIS 10.3 software using the ordinary kriging method with spherical model.

\section{RESULTS AND DISCUSSION}

For all data series, neither GD nor GEV distributions were rejected by the KS and AD adhesion tests. Although all distributions were adequate, the one with the best adherence was chosen (Table 2). In general, the GEV distribution showed better results, with this distribution being chosen for approximately $80 \%$ of stations. The GEV distribution obtained by the Lmoments method was highlighted with the best fitting in $32(73 \%)$ historical series. The Gumbel distribution is widely used for maximum annual rainfall (Ottero et al., 2018; Mistry and Suryanarayana, 2019). Notwithstanding, there are studies indicating that the GEV distribution has been shown to be superior to the Gumbel distribution (Beskow et al., 2015; Namitha and Vinothkumar, 2019).

Table 2 also presents the values of the coefficients of the IDF equation fitted for each station, the standard error values, and the coefficients of determination $\left(\mathrm{R}^{2}\right)$. For all stations, correlation coefficients greater than 0.991 and RMSE values ranging from 1.94 to $6.82 \mathrm{~mm} \mathrm{~h}^{-1}$ were obtained. Sabino et al. (2020) evaluated the fitting of the IDF equation for 14 rainfall stations in Mato Grosso State. The authors obtained a correlation coefficient $\left(\mathrm{R}^{2}\right)$ ranging from 0.8665 to 0.9596 , and RMSE ranging from 8.40 to $15.69 \mathrm{~mm} \mathrm{~h}^{-1}$. These data show the good quality of the fitting of IDF equations for Alagoas State.

The K coefficient values ranged from 268.5 to 1107.4 , and the $\mathrm{m}$ coefficient values ranged from 0.092 to 0.324 . Moreover, $b$ values approached 9.19 for all rainfall stations, and the $n$ coefficient values were equal to 0.706 . Other studies have already reported values practically constant for parameters $\mathrm{b}$ and $\mathrm{n}$ in fitting the coefficients of the IDF equation (Caldeira et al., 2015; Souza et al., 2012). Sabino et al. (2020) fitted IDF equations for 14 rainfall stations in Mato Grosso State and also observed a higher coefficient of variation in coefficients $\mathrm{K}$ and $\mathrm{b}$.

The $\mathrm{K}$ parameter is directly proportional to the rainfall intensity. The places where the highest values of this parameter were found coincide with the regions with the highest rainfall values, corresponding to the eastern/coastal region of tropical climate. In turn, the lowest $\mathrm{K}$ 
values are observed in the interior of the state, since in this region there is a dry climate. Therefore, there are coincidences with the characteristics of the Köppen climate classification, as already noted by Silva and Oliveira (2017).

Table 2. Coefficients of the fitted IDF equation with the respective RMSE and $\mathrm{R}^{2}$ values.

\begin{tabular}{|c|c|c|c|c|c|c|c|c|c|c|}
\hline \multirow{2}{*}{ No. } & \multirow{2}{*}{ Distribution } & \multicolumn{3}{|c|}{ Parameter } & \multicolumn{4}{|c|}{ Coefficient of the IDF equation } & \multirow{2}{*}{ RMSE } & \multirow{2}{*}{$\mathbf{R}^{2}$} \\
\hline & & $\alpha$ & $\beta$ & $\mathbf{k}$ & $\mathbf{K}$ & m & b & $\mathbf{n}$ & & \\
\hline 1 & MV & 048 & 74.2 & - & 742.1 & & 9. & 5 & 3.15 & 0.9975 \\
\hline 2 & GEV-MML & 33.24 & & 0.278 & 992.5 & & & & & \\
\hline 3 & GEV-MML & 39.09 & 67.30 & 0.189 & 815.1 & & 9 & & & 9910 \\
\hline 4 & GEV-MML & 23.18 & 68.09 & 0.007 & 704.9 & & 9.19 & 0.706 & 3.75 & 0.9966 \\
\hline 5 & GEV-MML & 40.27 & 80.62 & & 937.9 & & & & & \\
\hline 6 & GEV-MML & 39.62 & 100.59 & 0.211 & 1107.4 & 0.142 & 9.19 & 0.706 & 6.49 & 0.9942 \\
\hline 7 & GEV-MML & 24.13 & 80.03 & -0.243 & 734.9 & 0.282 & 9.19 & 0.706 & 2.81 & 0.9991 \\
\hline 8 & GEV-MM & 26.83 & 93.82 & 0.143 & 968.7 & & & & 4.27 & .9965 \\
\hline 9 & GD-CH & .049 & 64.67 & - & 660.6 & & 9.19 & 0.706 & 3.27 & 0.9970 \\
\hline 10 & GEV- & & & & & & & & & \\
\hline 11 & GEV & 17.35 & 47.09 & 0 & 497.2 & & & & 2.88 & 0.9960 \\
\hline 12 & GEV-MML & 18.21 & 63.85 & -0.020 & 637.3 & 0. & 9.19 & 0.706 & 2.77 & 0.9976 \\
\hline 13 & GEV-MML & 17.76 & & -0.093 & 656.9 & & & 06 & 2.44 & \\
\hline 14 & GD-CH & 0.053 & 42.69 & - & 466.8 & & 9.19 & 0.706 & 3.27 & 0.9952 \\
\hline 15 & GEV-MML & 25.10 & 66.02 & 0.460 & 730.3 & & 9.19 & 0.706 & 3.62 & 0.9943 \\
\hline 16 & GEV & 23.50 & & & 569.6 & & & & & \\
\hline 17 & GEV & 16.96 & 60.53 & -0.2 & 561.9 & & 9.19 & 0.706 & 2.03 & \\
\hline 18 & & & & & & & & & & \\
\hline 19 & GEV-MML & 15.44 & 60.88 & 0.007 & 602.7 & & 9. & 06 & 2.31 & 978 \\
\hline 20 & GD-CH & 0.064 & 38.28 & - & 411.0 & 0 & & 0.706 & 2.67 & 0.9956 \\
\hline 21 & GEV- & 3 & 59.51 & .026 & 702.1 & & & 06 & 6.23 & \\
\hline 22 & GEV-MML & 18.20 & 51.53 & -0.069 & 525.8 & & 9.19 & 0.706 & 2.88 & 971 \\
\hline 23 & GD-MMV & & & - & & & & & 3.92 & \\
\hline 24 & GEV & 09 & & 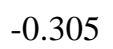 & & & 9 & 06 & 1.96 & 994 \\
\hline 25 & MML & 20.41 & 56 & 0 & 0 & & & 06 & 5 & 0.9951 \\
\hline 26 & & & & & & & & & & \\
\hline 27 & GEV-MML & 11.35 & & -0.116 & 268.5 & & & 0.706 & 1. & 0.9965 \\
\hline 28 & GEV-MML & 20.34 & & & & & & & 3.43 & \\
\hline 29 & IML & 12.53 & 6 & 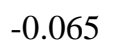 & & & 9. & 06 & 1.98 & 0.9971 \\
\hline 30 & GEV-MML & 20.28 & 50.05 & -0.0 & & 0 & & 0.706 & & 0.9957 \\
\hline 31 & & & & & & & & & & \\
\hline 32 & GEV-MML & & 40.10 & -0.103 & & & & 0.706 & & 0.9943 \\
\hline 33 & GEV-MML & 16.15 & & 0.004 & & & & 0.706 & 2.70 & 0.9960 \\
\hline 34 & GD-MMV & 0.048 & 52.10 & - & .5 & 5 & 9.20 & 0.706 & 3.48 & 0.9958 \\
\hline 35 & GEV-MML & 20.24 & 42.74 & -0.045 & 471.3 & 0.239 & 9.20 & 0.706 & 3.58 & 0.9953 \\
\hline 36 & GEV-MM & 18.60 & & & & & 9.19 & 0.706 & 3.18 & 0.9945 \\
\hline 37 & GEV-MML & 22.43 & 61.15 & 0.130 & 657.6 & 0.157 & 9.20 & 0.706 & 3.71 & 0.9952 \\
\hline 38 & GEV-MML & 23.91 & 71.38 & 0.044 & 742.8 & 0.174 & 9.19 & 0.706 & 3.88 & 0.9963 \\
\hline 39 & GEV-MML & & & & & & & & & \\
\hline 40 & GD-MM & 0.038 & & - & 627.0 & 0.218 & 9.19 & 0.706 & 4.57 & 0.9949 \\
\hline 41 & GD-MMV & 0.047 & & - & 570.6 & 0.206 & 9.19 & 0.706 & 3.63 & 0.9957 \\
\hline 42 & GD-MMV & 0.040 & 78.50 & - & 800.2 & 0.183 & 9.19 & 0.706 & 3.92 & 0.9970 \\
\hline 43 & GEV-MML & 30.94 & 82.40 & -0.076 & 850.0 & 0.228 & 9.20 & 0.706 & 5.00 & 0.9969 \\
\hline 44 & GEV-MM & 29.32 & 72.39 & 0.035 & 781.2 & 0.194 & 9.19 & 0.706 & 4.98 & 0.9953 \\
\hline
\end{tabular}

The fitting of IDF equations allowed estimating rainfall intensities for 15, 30, and 60 minutes with a 10-year return time, in addition to the maximum 1-day rainfall, using kriging to interpolate the data (Figure 2). The highest intensities occur on the coast, decreasing from east to west. Knowledge of IDF relationships, especially in places where hydrological monitoring 
is scarce, is an important tool for urban, agricultural, and environmental planning. Several engineering areas demand information about extreme rainfall, such as power generation, dams, civil construction, and urban drainage.
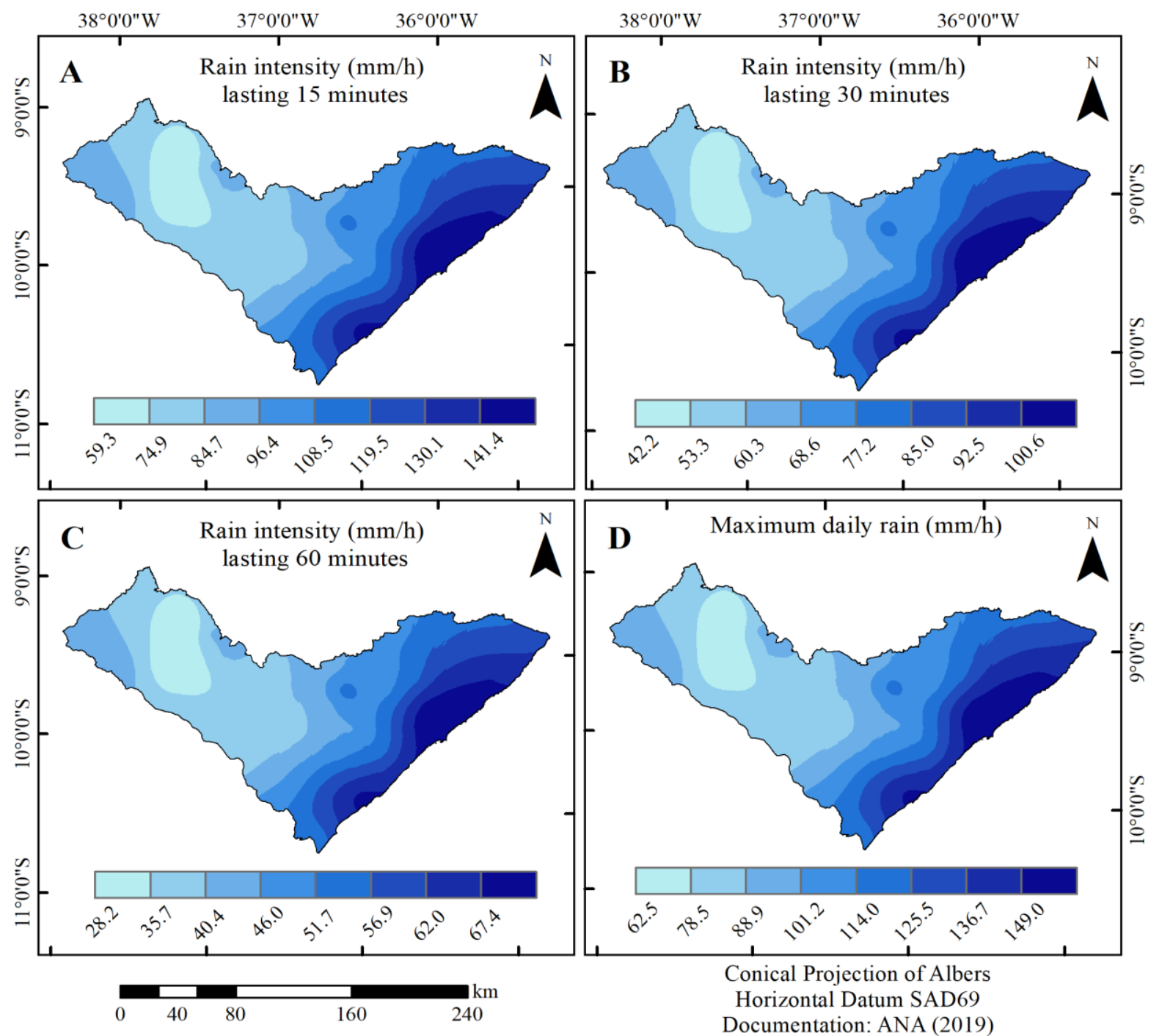

Figure 2. Rainfall intensity $\left(\mathrm{mm} \mathrm{h}^{-1}\right)$ for different durations with a 10-year return period, and maximum 1-day rainfall.

There is a marked spatial variation in maximum rainfall intensity in Alagoas State. Knowledge of this variation in rainfall intensity is important for planning water resource management actions as well as for soil conservation and engineering projects. The 5-minute rainfall intensity is used in the dimensioning of gutters to capture rainwater (Back and Bonetti, 2014). For soil conservation and gradient terracing, it is common to use the 15-minute rainfall intensity and a 10-year return period (De Maria et al., 2016). For level terraces, the maximum 1-day rainfall intensity and a 10-year return period is recommended. These values can be obtained from the IDF equations established for the rainfall stations in Alagoas (Table 2). The maximum 30-minute rainfall intensity is used as an indicator of the rainfall erosive potential. Therefore, Figure 2 indicates the locations with the greatest rainfall erosive potential in Alagoas State.

\section{CONCLUSIONS}

Alagoas' climate is quite varied, with tropical climate to the east and dry climate to the 
west. The highest averages of maximum annual rainfall coincide with the regions of tropical climate.

The series of maximum annual rainfall showed good fitting to Gumbel and GEV distributions, all of which were approved by the Kolmogorov-Smirnov and Anderson-Darling adhesion tests.

The GEV distribution with parameters obtained by the L-moments method was considered the best in $73 \%$ of rainfall stations.

The estimated IDF equations showed a good fit, with determination coefficients above 0.991. These equations allow estimating rainfall intensity from 5 minutes to 24 hours with a return period of 2 to 100 years, and standard error of $6.822 \mathrm{~mm} \mathrm{~h}^{-1}$.

There is a marked spatial variation in maximum rainfall intensity in Alagoas State, showing the need for hydrological studies addressing each climatic region of the state.

\section{REFERENCES}

BACK, Á. J.; BONETTI, A. V. Chuva de projeto para instalações prediais de águas pluviais de Santa Catarina. Revista Brasileira de Recursos Hídricos, v. 19, n. 4, p. 260-267, 2014. https://dx.doi.org/10.21168/rbrh.v19n4.p260-267

BARros, A. H. C.; ARAÚJO, J. C. F.; SILVA, A. B.; SANTIAGO, G. A. C. F. Climatologia do Estado de Alagoas. Dados eletrônicos. Recife: Embrapa Solos, 2012. 32 p. (Boletim de Pesquisa e Desenvolvimento).

BESKOW, S.; CALDEIRA, T. L.; MELLO, C. R.; FARIA, L. C.; GUEDES, H. A. S. Multiparameter probability distributions for heavy rainfall modeling in extreme southern Brazil. Journal of Hydrology: Regional Studies, 4B, p. 123-133. 2015. https://dx.doi.org/10.1016/j.ejrh.2015.06.007

CALDEIRA, T. L.; BESKOW, S.; MELLO, C. R. de; VARGAS, M. M., GUEDES, H. A. S.; FARIA, L. C. Daily rainfall disaggregation: an analysis for the Rio Grande do Sul state. Scientia Agraria, v. 16, n. 3, p. 1- 21, 2015. http://dx.doi.org/10.5380/rsa.v16i3.46320

CETESB. Drenagem urbana: manual de projetos. São Paulo: DAEE/CETESB, 1986.

COELHO FILHO, J. A. P.; MELO, D. C. R.; ARAÚJO, M.L.M. Estudo de chuvas intensas para a cidade de Goiânia/GO por meio da modelação de eventos máximos anuais pela aplicação das distribuições de Gumbel e Generalizada de Valores Extremos. Ambiência, v. 13, n. 1, p. 75-88, 2017. https://dx.doi.org/10.5935/ambiência.2017.01.05

DE AlCÂNTARA, L. R. P.; COUTINHO, A. P.; SANTOS NETO, S. M.; DE MELO, T. A. T.; COSTA; L. V.; RIBAS, L. V. S; ANTONINO, A. C. D; ALVES, E. M. Modelos probabilísticos para eventos de precipitações extremas na cidade de Palmares-PE. Revista Brasileira de Geografia Física, v. 12, n. 4, p. 1355-1369, 2019. https://dx.doi.org/10.26848/rbgf.v12.4.p1355-1369

DE MARIA, I. C.; DRUGOWICH, M. I.; BORTOLETTI, J. O.; VITTI, A. C.; ROSSETTO, R.; FONTES, J. L., TCATCHENCO, J., MARGATHO, S. F. Recomendações gerais para a conservação do solo na cultura da cana-de-açúcar. Campinas: IAC, 2016. 100 p. (Boletim Técnico IAC, 216).

DENG, S.; LI, M.; SUN, H.; CHEN, Y.; QU, L. ZHANG, X. Exploring temporal and spatial variability of precipitation of Weizhou Island, South China. Journal of Hydrology: Regional Studies, v. 9, p. 183-198, 2017. https://dx.doi.org/10.1016/j.ejrh.2016.12.079 
DIAS, E. C.; PENNER, G. C. Contabilização de equações de Intensidade-Duração-Frequência disponíveis no Brasil. Anuário do Instituto de Geociências, v. 42, n. 1, p. 209-216, 2019. http://dx.doi.org/10.11137/2019_1_209_216

GONÇALVES, L. J.; TAGLIAFERRE, C.; CASTRO FILHO, M. N; BRITO NETO, R. L.; SILVA, B. L; ROCHA, F. A. Determination of intensity-duration-frequency equations for sites in Bahia state. Irriga, v. 1, n. 1, p. 109-115, 2019. https://dx.doi.org/10.15809/irriga.2019v1n1p109-115

MARRA, F.; MORIN, E.; PELEG, N.; MEI, Y.; ANAGNOSTOU, E. N. Intensity-durationfrequency curves from remote sensing rainfall estimates: comparing satellite and weather radar over the eastern Mediterranean. Hydrolog. Earth Syst. Sci, v.21, p.2389-2404, 2017. https://dx.doi.org/10.5194/hess-21-2389-2017

MARTINS, D.; KRUK, N. S.; MAGNI, N. L. G.; QUEIROZ, P. I. B de. Comparação de duas metodologias de obtenção da equação de chuvas intensas para a cidade de Caraguatatuba (SP). Revista DAE, p. 34-49, 2017. https://dx.doi.org/10.4322/dae.2016.033

MIRZAEI, M.; HUANG, Y.; LEE, T. S.; EL-SHAFIE, A.; GHAZALI, A. H. Quantifying uncertainties associated with rainfall depth duration frequency curves. Natural HazardsSpringer, v. 71, n. 2, p. 1227-1239, 2014. https://dx.doi.org/10.1007/s11069-013-0819-3

MIRZAEI, M.; HUANG, Y. F.; EL-SHAFIE, A.; CHIMEH, T.; LEE, J.; VAIZADEH, N.; ADAMOWSKI, J. Uncertainty analysis for extreme flood events in a semi-arid region. Natural Hazards, v. 78, n. 3, p. 1947-1960, 2015. https://dx.doi.org/10.1007/s11069015-1812-9

MISTRY, P. B.; SURYANARAYANA, T. M. V. Estimation of Annual One Day Maximum Rainfall using Probability Distributions for Waghodia Taluka, Vadodara. Global Research and Development Journal for Engineering, p. 296-300, 2019.

NAGHETTINI, M.; PINTO, É. J. A. Hidrologia Estatística. Belo Horizonte: CPRM, 2007.

NAMITHA, M. R.; VINOTHKUMAR, V. Development of empirical models from rainfallintensity-durations-frequency y curves for consecutive Day maximum rainfall using GEC distribution. Journal of Pharmacognosy and Phytochemistry, v. 8, n. 1, p. 275-2709, 2019.

OLOFINTOYE, O. O.; SULE, B.F.; SALAMI, A.W. Best-fit probability model for peak daily rainfall of selected Cities in Nigeria. New York Science Journal, v. 2, n. 3, p. 1-12, 2009.

OTTERO, C. R.; CHARGEL, L. T.; HORA, M. A. G. M. Análise de frequência dos dados pluviométricos observados em 2011 a 2013 na região Serrana do Rio de Janeiro. Revista Brasileira de Meteorologia, São Paulo, v.33, n.1, p.131-139, 2018. https://dx.doi.org/10.1590/0102-7786331007

OUALI, D.; CANNON, A. J. Estimation of rainfall intensity-duration-frequency curves at ungauged locations using quantile regression methods. Stochastic Environmental Research and Risk Assessment, v. 32, p. 2821-2836, 2018. https://dx.doi.org/10.1007/s00477-018-1564-7.0123

PENNER, G. C.; LIMA, M. P. Comparação entre métodos de determinação da equação de chuvas intensas para a cidade de Ribeirão Preto. Geociências, v. 35, n. 4, p. 542-559, 2016. 
PETRUCCI, E.; OLIVEIRA, L. A. Relações entre intensidade, duração e frequência das precipitações máximas de 24 horas e equação de chuvas intensas para a cidade de Uberlândia-MG. Revista Brasileira de Climatologia, ano 15, v. 25, p. 337-354, 2019. https://dx.doi.org/10.5380/abclima.v25i0.57767

QUADROS, L. E.; QUEIROZ, M. M. F.; VILAS BOAS, M. A. Distribuição de frequência e temporal de chuvas intensas. Acta Scientiarum, v. 33, n. 3, p. 401-410, 2011. https://dx.doi.org/10.4025/actasciagron.v33i3.6021

RANGEL, E. M.; HARTWIG, M. P. Análise das curvas de intensidade-duração-frequência para a cidade de Pelotas através de uma função de desagregação. Revista Thema, v. 14, n. 2, p. 63-77, 2017. https://dx.doi.org/10.15536/thema.14.2017.63-77.353

SABINO, M.; SOUZA, A. P.; ULIANA, E. M.; LISBOA, L.; ALMEIDA, F. T.; ZOLIN, C. A. Intensity-duration-frequency of maximum rainfall in Mato Grosso State. Revista Ambiente \& Água, v. 15, n. 1, e2373, 2020. https://dx.doi.org/10.4136/ambi-agua.2373

SILVA, C. B.; OLIVEIRA, L. F. C. Relação Intensidade-Duração-Frequência de chuvas extremas na região Nordeste do Brasil. Revista Brasileira de Climatologia, ano 13, v. 20, p. 267-283, 2017. https://dx.doi.org/10.5380/abclima.v20i0.49286

SILVEIRA, A. L. L da. Equações cumulativas sequenciais do hietograma do método de Chicago. Revista Brasileira de Recursos hídricos, v. 21, n. 3, p. 646-651, 2016. https://dx.doi.org/10.1590/2318-0331.011615094

SOUZA, R. O. R. M.; SCARAMUSSA, P. H. M.; AMARAL, M. A. C. M.; NETO, J. A. P.; PANTOJA, A. V.; SADECK, L. W. R. Equações de chuvas intensas para o estado do Pará. Revista Brasileira de Engenharia Agrícola e Ambiental, v. 16, n. 9, p. 999-1005, 2012. https://dx.doi.org/10.1590/S1415-43662012000900011

TFWALA, C. M.; VAN RENSBURG, L. D.; SCHALL, R.; MOSIAM S. M.; DLAMINI, P. Precipitation intensity-duration-frequency curves and their uncertainties for Ghaap $\begin{array}{lllllll}\text { plateau. Climate Risk Management, v. } & \text { 16, } & \text { p. } & 1-9,17 .\end{array}$ https://dx.doi.org/doi.org/10.1016/j.crm.2017.04.004 